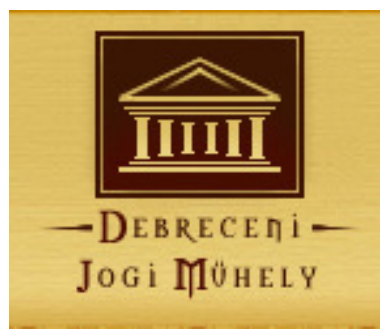

\title{
Petkó Mihály1: A szabadalmi jogi szerződés és hatásai a hazai jogban
}

Globalizálódó világunkban a jogintézményekkel és eljárásokkal szemben egyre fontosabb elvárás, hogy minél egyszerübben, gyorsabban és könnyebben lehessen a kívánt jogi célokat elérni. A technika e célkitüzések megvalósításában jelentős szerepet játszik, segítséget nyújt, hogy a világ bármely pontjáról elérhető legyen az adott eljárás lefolytatására jogosult hatóság, akár személyes találkozás - és az ezzel járó költségek - nélkül teljesüljön a joghatás. A technikai feltételek adottságaira, valamint az ennek köszönhető megváltozott elvárásokra figyelemmel a jogalkotás is igyekszik standardizálni eljárásait, egyszerübbé, könnyen érthetővé tenni az eljárás lefolytatásához szükséges beadványok tartalmát, illetve minél kevesebb bürokratikus elemet beiktatni a szükséges jogi eljárásba.

A szellemi alkotások joga mindig is egy olyan terület volt, ahol a nemzetközi jelleg meghatározó szerepet játszott, hiszen a létrehozott szellemi termék jogosultjának legfőbb érdeke az, hogy alkotását a lehető legteljesebb körü védelem illesse meg. Hazánk az elsők között csatlakozott azokhoz a nemzetközi egyezményekhez, melyek ezt lehetővé tették. Ez a tendencia azonban napjainkban változatlanul jelen van, a megváltozott nemzetközi jogi, technikai háttér időről időre szükségessé teszi, hogy újabb és újabb olyan megállapodások szülessenek, melyek hozzásegítik az alkotókat, feltalálókat jogaik minél teljesebb védelméhez.

Az iparjogvédelem területén ez a jellemző megfigyelhető volt szabadalmi törvényünk 2002. évi módosításánál, melynek eredményeképpen 2003. január 01. napjával Magyarország tagjává vált az Európai Szabadalmi Egyezménynek. Az Egyezmény fő célja az volt, hogy egyszerübbé, hatékonyabbá tegye valamely találmány több európai országban való szabadalmaztatását. Ezt a racionalizálási célt úgy érte el, hogy egy adott találmányra vonatkozó azonos tartalmú nemzeti bejelentések sokasága helyett egyetlen, az Egyezmény valamennyi tagállamára kiterjedő, multinacionális jogi hatályú európai bejelentés tehető, amelyet párhuzamos nemzeti eljárások sokasága helyett egyetlen centralizált eljárásban, egységes szabályok szerint bírálnak el. Az Egyezmény hármas célja a közös egységes alaki, eljárási és anyagi, az európai jogra alapozott, magas szintű szabadalomengedélyezés, központi érdemi vizsgálat, a tagállamok és az Európai Szabadalmi Hivatal közti együttmüködés.

Az európai szabadalmi egyezmény, amelynek Magyarország 2003. január 1-je óta tagja, 2000-ben átfogó vizsgálat alá került. A változást kikényszerítő körülmények közé tartozott különösen az európai integráció elmélyülése, az innováció felértékelődése az élesedő világgazdasági versenyben, a nemzetközi jogfejlődés, az Európai Szabadalmi Hivatal munkaterhének radikális növekedése, a kutatásra és fejlesztésre épülő iparágak megerősödése, valamint számos olyan technológia megjelenése és robbanásszerü fejlődése, amelyeknek a szabadalmi jogban megfelelő leképezést és megoldást kellett kapniuk. 2 Az "európai szabadalmi egyezmény 2000" egyebek mellett módosította az első és további gyógyászati indikáció szabadalmaztathatóságára, az oltalom terjedelmére, a vizsgálat és a jogorvoslat 
rendjére vonatkozó szabályokat, illetve bevezette az európai szabadalmak központi korlátozásának lehetőségét.

Az egyezmény felülvizsgált szövege 2007. december 13-án lépett hatályba. Ennek fontos következménye volt, hogy azok az államok, amelyek a felülvizsgált szöveget nem erösítik meg, illetve ahhoz nem csatlakoznak annak hatálybalépésig, elveszítik az egyezményben fennálló tagságukat is.

A szabadalmi törvényünk nemzetközi jellegének erösödését eredményező tendenciák között feltétlenül meg kell azonban említeni a Szellemi Tulajdon Világszervezetében (World Intellectual Property Organization; a továbbiakban: WIPO) 2000. június 1-jén, Genfben elfogadott Szabadalmi Jogi Szerződést (Patent Law Treaty, vagy PLT), amelynek alapvető célja a nemzeti és a regionális úton tett szabadalmi bejelentésekre vonatkozó alaki követelmények harmonizálása, valamint a szabadalom megszerzésére és fenntartására irányuló eljárások egyszerüsítése. A két szerződés között az alapvető különbség az azt létrehozó és ahhoz csatlakozott tagállamok kilétében és számában van.

A Szabadalmi Jogi Szerződés, amelyet az annak létrehozását célzó diplomáciai értekezleten Magyarország is aláírt, 2005. április 28-án lépett hatályba. Az Szabadalmi Jogi Szerződésnek jelenleg 15 állam, közöttük 7 EU tagállam részese: Bahrein, Dánia, az Egyesült Királyság, Észtország, Finnország, Horvátország, Kirgizisztán, Moldova, Nigéria, Omán, Románia, Szlovákia, Szlovénia, Ukrajna és Üzbegisztán. Az aláírók között szerepel többek között az ESZSZ és az Amerikai Egyesült Államok is.

A Szabadalmi Jogi Szerződés által kitüzött célok az Európai Szabadalmi Egyezményéhez nagyban hasonlítanak, azonban számos tekintetben hiánypótló jellegüek. A Szerződés szerint fontos a bejelentés napjára vonatkozó követelmények és eljárási szabályok harmonizálása annak érdekében, hogy elkerülhető legyen a bejelentés napjának „elvesztése” az alaki szabályok be nem tartása miatt, mivel a bejelentéshez a szabadalmi jog számos lényeges joghatást kapcsol. Az egyszerüsítés érdekében a Szerződés egyetlen, nemzetközi szinten harmonizált alaki követelményrendszer támaszt a nemzeti és a regionális úton tett szabadalmi bejelentések tekintetében, amely összhangban van a Szabadalmi Együttmüködési Szerződésben (PCT) meghatározott alaki előírásokkal. Egységesített űrlapok létrehozását írja elő, amelyeknek adattartalmát a Szabadalmi Jogi Szerződésben részes valamennyi állam hivatalának el kell fogadnia. A tagállami és a regionális szabadalmi hivatalok előtt folyó eljárás egyszerüsítése és az e hivatalok előtti képviseletre vonatkozó előírások enyhítése szintén megvalósítandó feladat, akárcsak a határidők elmulasztása miatt bekövetkező jogvesztés elkerülésére szolgáló mechanizmusok kialakítása.

A Szabadalmi Jogi Szerződés tehát többségében eljárásjogi követelményeket támaszt a részes tagállamokkal szemben, a bejelentési eljárások formalizálása, ezáltal egyszerűsítése az elérendő cél, illetve az eljárás határidejéhez füződő joghatások változtatása, pontosítása. Az Szabadalmi Jogi Szerződés a követelmények maximumának megállapításával összehangolja és egyszerüsíti a nemzeti és a regionális szabadalmi hivatalok által előírható alaki feltételeket. Előnyt jelent a bejelentők és a képviselők számára, hogy az eljárások egyszerübbé, kiszámíthatóbbá válnak, továbbá a jogvesztés veszélye nélkül van mód a hiányok pótlására. A Szabadalmi Jogi Szerződés a szerződő országok hivatalai által maximálisan elöírható követelmények együttesét határozza meg. Ez azt jelenti, hogy a szerződő országok - bizonyos kivételektől eltekintve - szabadon dönthetnek úgy, hogy enyhébb, "nagyvonalúbb" követelményeket támasztanak a bejelentők, szabadalmasok felé. A Szerződés előírásai éppúgy 
vonatkoznak a nemzeti és a regionális szabadalmi bejelentésekre és szabadalmakra, mint a PCT alapján benyújtott nemzetközi bejelentésekre az ún. "nemzeti szakaszba" lépést követően.

A hivatalok szemszögéből pedig az Szabadalmi Jogi Szerződés a hatékonyabb múködés lehetőségét kínálja. A harmonizációt célzó rendelkezéseken felül az Szabadalmi Jogi Szerződés létrehozza a tagországok képviselőiből álló Közgyülést, amelynek legfőbb hatásköre az Szabadalmi Jogi Szerződés mellékletét képező Végrehajtási Szabályzat módosítása és a nemzetközi ürlapminták elfogadása. Ezáltal lehetővé válik, hogy az Szerződés által nyújtott szabályozás folyamatosan követni tudja a szabadalmi eljárások körülményeinek változását és az újabb fejleményeket, a Közgyülés ugyanis biztosítja az ehhez szükséges rugalmas döntéshozatali mechanizmust (17. cikk). Az Szerződés végül rendelkezik többek között a Végrehajtási Szabályzat tartalmára és módosítására vonatkozó szabályokról (14. cikk), a WIPO Nemzetközi Irodájának az SZJSZ mủködtetéséből adódó feladatairól (18. cikk), az Szerződés hatálybalépéséről (21. cikk), felülvizsgálatáról (19. cikk) és az ahhoz való csatlakozás szabályairól (20. cikk).

A Szabadalmi Jogi Szerződés egyik alapelve, hogy a benne foglalt követelmények maximumot jelentenek. Ez azt jelenti, hogy a szerződő felek szabadságában áll a bejelentők vagy a szabadalomtulajdonosok érdekében a szerződéshez képest kedvezőbb előírásokat alkalmazni, kivéve a bejelentési nap elismerésének feltételeivel kapcsolatban. A Szerzői Jogi Szerződés tehát a szabadalmi bejelentések alakját, tartalmát és bizonyos eljárási szabályokat illetően meghatározza a követelmények maximumát, amelyeknél az egyes szerződő államok többet nem, legfeljebb kevesebbet írhatnak elő. A másik alapelv egyértelműen leszögezi, hogy a szerződő felek saját anyagi jogi rendelkezéseiket szabadon alkalmazhatják, vagyis a Szabadalmi Jogi Szerződés kizárólag eljárási kérdéseket rendez.

Szabadalmi törvényünk anyagi része is némiképp módosult, amikor kimondja, hogy a találmányra szabadalmat kell adni, ha a találmány kielégíti az 1-5/A. §-okban foglalt követelményeket, valamint nincs kizárva a szabadalmi oltalomból. A találmány nem részesülhet szabadalmi oltalomban, ha gazdasági tevékenység körében történő hasznosítása a közrendbe vagy a közerkölcsbe ütközne; az ilyen hasznosítás nem tekinthető a közrendbe ütközőnek pusztán azért, mert valamely jogszabállyal ellentétben áll. Nem részesülhetnek szabadalmi oltalomban az emberi vagy állati test kezelésére szolgáló gyógyászati vagy sebészeti eljárások, valamint az emberi vagy állati testen végezhető diagnosztikai eljárások. E rendelkezés az ilyen eljárásokban alkalmazott termékre - így különösen anyagra (vegyületre) és keverékre - nem vonatkozik.3. Az idézett jogszabályszövegből kitünik, hogy a szabadalmi oltalom elnyerésének szabályozása jóval rugalmasabb lett. 
A változások az eljárás mederben tartására is kiterjedtek, ennek köszönhetően, ahol a törvény nem állapít meg határidő́t a hiánypótlásra, illetve a nyilatkozattételre, az ügyfél részére legalább két hónapos, de legfeljebb négy hónapos határidőt kell kitüzni, amely a lejárat előtt előterjesztett kérelemre legalább két hónappal, de legfeljebb négy hónappal meghosszabbítható. Különösen indokolt esetben adható többszöri, illetve négy hónapot meghaladó, de legfeljebb hat hónapos határidő-hosszabbítás is.4 Az új szabályozás tehát kedvező a bejelentő számára a hosszabb határidő miatt, azonban gátat is szab az eljárás túlzott elnyúlásának véghatáridőivel.

Különösen az egyéni bejelentők és a kisvállalatok szempontjaira tekintettel került megfogalmazásra a Szabadalmi Jogi Szerződés azon rendelkezése, amely szerint meghatározott ügyekben a szerződő felek nem kívánhatják meg, hogy a bejelentő, a szabadalom tulajdonosa vagy egyéb érdekelt személy képviselő útján járjon el hivataluk előtt. Ezek az ügyek a következök:

- a bejelentés benyújtása a bejelentési nap elismerése céljából,

- valamely díj puszta megfizetése,

- a Végrehajtási Szabályzatban előírt bármely egyéb eljárás,

- az előzőekben említett bármely eljárásra vonatkozóan a hivatal által adott elismervény vagy értesítés.

Ezekben az ügyekben tehát a bejelentő, a szabadalom tulajdonosa vagy ezek jogutódja és más érdekelt személyek maguk járhatnak el a hivatalok előtt. Lényeges eleme a szabályozásnak, hogy a fenntartási díjakat bármilyen megkötés nélkül, bárki megfizetheti. Ez a szabályozás átültetésre került a magyar szabályozásban.

A Szabadalmi Jogi Szerződés kötelezővé teszi, hogy a szerződő államoknak a hivatalaik által kitüzött határidők elmulasztása esetére jogorvoslatot kell biztosítaniuk. Ez a bejelentők szempontjából egy fontos garanciális szabály. A jogorvoslat lehetséges határidő-hosszabbítás engedélyezése, vagy ha ezt az adott ország jogszabályai nem teszik lehetővé, az eljárás folytatása (continued processing révén.

A fenti szabályok nyomán enyhültek a nem orvosolható határidőkre vonatkozó szabályok, a szabadalmi törvény az elmulasztott határnaptól, illetve az elmulasztott határidő utolsó napjától számított két hónapon belül igazolási kérelmet lehet elöterjeszteni, ha a mulasztás az ügyfél önhibáján kívül következett be. Az igazolási kérelemben valószínúsíteni kell a mulasztás okát és vétlenségét. Ha a mulasztás az ügyfélnek később jutott tudomására, vagy az akadály később szünt meg, a határidő a tudomásra jutástól vagy az akadály elhárulásától számít. Az elmulasztott határnaptól, illetve az elmulasztott határidő utolsó napjától számított tizenkét hónapon túl igazolási kérelmet nem lehet előterjeszteni. 
A Szabadalmi Jogi Szerződés szerint a megadott szabadalmak nem vonhatók meg és nem semmisíthetők meg anélkül, hogy a szabadalom tulajdonosának módja lenne ezzel kapcsolatban észrevételt tenni vagy a szabadalmat módosítani. Lényeges ebben a vonatkozásban, hogy alaki hiányok miatt - különleges esetektől eltekintve - nincs helye a szabadalom megvonásának vagy megsemmisítésének.

Hatályos szabályozásunk a fenti rendelkezéseknek megfelel, kimondja, hogy a Magyar Szabadalmi Hivatal a megsemmisítési kérelemmel kapcsolatban nyilatkozattételre hívja fel a szabadalmast és - szolgálati találmányra adott szabadalom esetén - a feltalálót, majd írásbeli előkészítés után szóbeli tárgyalás alapján határoz a szabadalom megsemmisítéséről, korlátozásáról vagy a kérelem elutasításáról. Az eljárást befejező végzés tárgyaláson kívül is meghozható. $\underline{5}$

Szabadalmi jogunk kimondja, hogy a Szabadalmi Jogi Szerződés és e törvény második része közötti eltérés esetén a bejelentő és a szabadalmas számára kedvezőbb rendelkezést kell alkalmazni, kivéve, ha a Szabadalmi Jogi Szerződés erről eltérően rendelkezik. Ha a szabadalmi ügyben elöterjesztett beadvány megfelel a Szabadalmi Jogi Szerződésben megszabott követelményeknek, a szabadalmi törvényben, illetve a törvény alapján elöírt - azonos tárgyú - követelményeket is teljesítettnek kell tekinteni, azoknak a követelményeknek a kivételével, amelyeket e törvény vagy e törvény alapján más jogszabály a Szabadalmi Jogi Szerződésben kapott felhatalmazás szerint ír elö.므

A Szabadalmi Jogi Szerződés és az Európai Szabadalmi Egyezmény több esetben párhozamosan hat egymás mellett, ami nem véletlen, hiszen a célok nagy része közös. Ugyanakkor kérdésként merülhet fel, hogy nem zavaró e a párhuzamosság, illetve szükség van e rá. Erre ekként lehet válaszolni, hogy a Szabadalmi Jogi Szerződés az eljárás általános egyszerüsítését, gyorsabbá, olcsóbbá tételét célozza, vagyis a korábbi szabályok módosítása által lehetővé válik az elektronikus eljárás, illetve számos a bejelentő számára kedvező eljárási szabály jelenik meg. Az európai szabadalom esetén viszont a szabadalom egy másik szinten az Európai Szabadalmi Közlönyben való meghirdetése által minősül megadottnak. Az európai szabadalom esetében tehát egy másik védelmi lehetőségről van szó, mely - bár azonos hatályú a hazai hatóság által megadott szabadalommal - mégis, mivel mögötte az európai közösség és annak szervei állnak, biztosabb védelmet jelenthet a jogosultnak.

A Szabadalmi Jogi Szerződés szabályainak átvétele, beépítése tehát semmiképpen sem zavaró, hiszen azok csupán általánosságban igyekszenek a bejelentő helyzetét könnyíteni, míg az európai szabadalom egy másik szintü fórumrendszert jelent elsősorban, és az annak müködéséhez szükséges eljárási szabályokat.

Mindazonáltal szerencsés lenne a nemzetközi szabályok közötti további harmonizáció a jogforrások számának csökkentése érdekében azért, hogy a jogalkalmazónak ne kelljen egyszerre három jogforrás rendelkezései között keresnie.

Komoly elörelépésként értékelhető a szabadalmi bejelentés elektronikus úton történő benyújtásának lehetősége. Sajnálatos viszont, hogy az eljárás egészének elektronikus úton való intézése kizárt, hiszen elsősorban ez segíthetné elő a gyors és hatékony eljárást. 
Álláspontom szerint az ügyek jellege nem zárja ki, sőt a szellemi alkotások jogterületére jellemző nemzetközi jelleg, kifejezetten kívánatossá tenné az eljárás elektronikus úton való lefolytatását, ami nyilvánvalóan a kérelmezőknek sem jelentene az eddigieknél súlyosabb anyagi terheteket, hiszen ezekben az eljárásokban a költségmentesség kizárt, a kérelmezők általánosságban pedig rendelkeznek a megfelelő anyagi eszközökkel. Az elektronikus eljárás bevezetésének így leginkább a hatóság oldalán felmerülő anyagi akadályai lehetnek.

A Szabadalmi Jogi Szerződésnek kifejezetten az lenne a célja, hogy - egyenlőre - mind a hagyományos papír alapú, mind az elektronikus ügyintézést lehetővé tegye. Ez a hazai törvény alapján felemásan valósul meg, hiszen a bejelentés megtétele adott mindkét formában, az eljárás többi szakaszában viszont a papír alapú ügyintézés maradt meg, ami okozhat kellemetlenségeket a bejelentőnek. A Szerződés nem akar diszkriminálni egyenlöre az eljárások módjai által, ám a tendenciákat figyelembe véve érzékelhető, hogy az elektronikus eljárás és ügyintézés bevezetése lesz a cél.

A szabadalmi törvény módosítása mindenképpen liberalizációt eredményez, hiszen a bejelentés egyszerübb, az eljárások egyszerübbek lesznek, mindez pedig azt szolgálja, hogy az üzleti körökben fennmaradjon az érdeklődés, bizalom. Ily módon sikerül csökkenteni a bürokratikus elemeket az eljárásban, a bejelentők jóval egyszerűbben, nagyvonalúbb szabályok mentén járhatnak el. E ponton azonban szükséges felhívni arra a figyelmet, hogy bár a beiktatott szabályok komoly segítséget nyújtanak a bejelentőknek, jogosultaknak, azonban a túlzott liberalizációtól óvakodnék e körben, vagyis az eljárás túlzott egyszerüsítése a kérelem Szabadalmi Hivatal által történő elbírálását lehetetleníti el, melyről egyenlőre nincsen szó.

A Szabadalmi Jogi Szerződés szabályainak implementálása egyelőre mindenképpen szerencsés, hiszen a nemzetközi szinten egységes szabályok és nyomtatványok használata előnyt jelent, hogy a szerződő országok állampolgárai egy külföldi bejelentés megtételekor ismerös környezettel állnak majd szemben.

A leírtak alapján érzékelhetővé váló tendencia szerint napjainkban a szabadalmi jog területén is a nemzetközi szinten történő összehangolás, egységesítés jelenik meg, ez azonban egyenlöre csak az eljárási szabályok szintjén jelentkezik. Hosszútávon azonban mindenképpen szerencsés lenne, ha nemcsak az egyes nemzeti hatóságok által lefolytatott eljárások közelednének egymáshoz, hanem a jogi oltalom feltételeinek szabályozása is.

Elöretekintve elmondható tehát, hogy a Szabadalmi Jogi Állandó Bizottság (Standing Committe on the Law of Patents, rövidítve SCP) elmúlt ülésszakain éppúgy, mint a WIPO Közgyülés 1999. szeptemberi ülésén, igen sok delegáció adott hangot azon véleményének, hogy a PLT-vel kapcsolatos eredmények megszületését követően a harmonizációs folyamat nem torpanhat meg, itt az idő, hogy a szabadalmi jog további harmonizálása kerüljön előtérbe. A WIPO a további harmonizációt a 2000-2001. évi munkaprogramja részeként kezeli, az SCP ezzel foglalkozó első munkaülésére ez év novemberében sor kerül. Sokan remélik, hogy a néhány évvel ezelőtt zátonyra futott anyagi jogi harmonizációt célzó tárgyalások ezúttal jobb esélyekkel folytatódhatnak.

Érdemes talán itt szó szerint idézni Kamil Idrisnek, a WIPO főigazgatójának szavait: „A PLT sikeres létrehozása lényeges lépésnek tekinthető a szabadalmazással összefüggő költségek "világméretü" csökkenésének tágabb folyamatában. A következő lépés a további jogi 
kérdések harmonizálását célzó munka, amely végül is egyetlen, globális oltalmazási feltételrendszer kialakításához vezet.”프

1 Egyetemi adjunktus, Debreceni Egyetem Állam- és Jogtudományi Kar, Polgári Jogi Tanszék

2 Takács Albert igazságügyi miniszteri előterjesztése, www.irm.gov.hu/?mi=1\&katid=2\&id=110\&cikkid=4316 $-31 \mathrm{k}$

$\underline{3}$ A találmányok szabadalmi oltalmáról szóló 1995. évi XXXIII. tv. (Szt.) 6. § (2) és (10) bekezdése

4 Szt. 13. § (2) bekezdése

$\underline{5}$ Szt. 81. § (1) bekezdése

6 Szt. 53/E. $\S$

$\underline{7}$ http://www.wipo.int/classifications/ipc/en/circular/index.html 